\title{
JOURNAL.RU
}

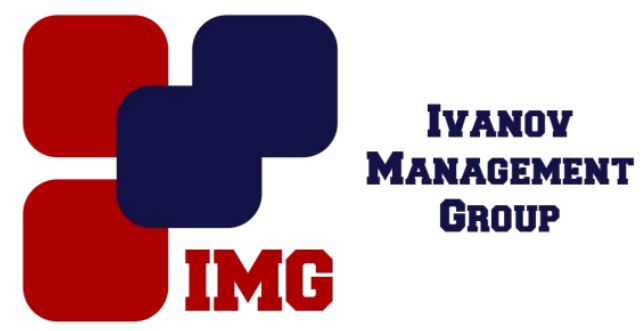

Добрынкина О.В.

Муромский институт (филиал) ФГБОУО «Владимирский государственный университет имени Александра Григорьевича и Николая Григорьевича Столетовых»

Муром, Россия

doi: 10.18411/lj-31-01-2017-2-03

idsp 000001:lj-31-01-2017-2-03

\section{Проблемы управления дебиторской задолженности в жилищно- коммунальной отрасли}

\begin{abstract}
Аннотация
Данная статья посвящена характеристике дебиторской задолженности, рассмотрены основные элементы системы управления дебиторской задолженностью и специфические инструменты, применяемые в организациях жилищно-коммунального хозяйства. Рассмотрены основные проблемы, даны рекомендации по вопросу управления дебиторской задолженностью в жилищнокоммунальной отрасли.

Ключевые слова: дебиторская задолженность, мероприятия по взысканию дебиторской задолженности, анализ дебиторской задолженности, досудебное взыскание задолженности, судебный порядок взыскания задолженности.

Кризис, связанный с изменением курса валют в 2014-2015 гг., негативно отразился на выплатах по обязательствам физических и юридических лиц. Специалисты из разных областей, таких, как кредитование, розница, оказание услуг фиксируют положительную динамику в увеличении числа должников. Физические и юридические лица отказываются платить по обязательствам договоров аренды, кредитования, оказания услуг, поставку.

Не обошла стороной печальная тенденция и сферу оказания жилищнокоммунальных услуг. По данным Росстата, средняя задолженность за оплату жилищно-коммунальных услуг перед исполнителями (УК, ТСЖ, ЖСК) выросла с начала 2016 года уже на 15 \%. Учитывая традиционный летний спад платежей, к осеннему сезону общий размер задолженности приблизился к 20-25\%.

В денежном эквиваленте средняя сумма задолженности перед лицами, осуществляющими управление жилой недвижимостью, составляет около 700000 руб., и уже в первые месяцы эффективной работы, долги снижаются минимум на 30\%, ведь многим должникам достаточно просто корректно напомнить о
\end{abstract}


задолженности.

Если же своевременно не заниматься задолженностью, то суммы долгов возрастают в разы и нередко переваливают за миллионы рублей. Довольно немаленькая сумма, которая требует своевременной работы по взысканию, потому что дальше эта сумма будет только расти. Самообман думать, что само как то разрешится, никаких оснований полагаться на «авось» в условиях кризиса нет. Пора уже понять, что многие должники не платят не из-за крайней степени бедности или временного отсутствия денег, а не платят, потому что никто их не стимулирует своевременно и полностью платить.

Плата за ЖКУ вносится ежемесячно до 10 (десятого) числа месяца, следующего за истекшим месяцем.

Неиспользование физическим или юридическим лицом, владеющим на праве собственности частью жилого здания, а также лицом, эксплуатирующим помещения на основании договора найма, договора аренды или на ином законном основании (далее - Собственником) помещений не является основанием невнесения оплаты.

В случае несвоевременной и (или) неполной оплаты ЖКУ Собственник несет ответственность в соответствии с Жилищным кодексом РФ и Договором на управление многоквартирным жилым домом.

Мероприятия по взысканию дебиторской задолженности включают в себя обязательные и дополнительные меры. Дополнительные мероприятия назначают в форме и количестве, необходимом для снижения суммарной Дебиторской задолженности Собственников жилых и нежилых помещений.

Планирование работы по взысканию Дебиторской задолженности:

1. До 5 (пятого) числа каждого месяца управляющий инвестированием чистых активов общества, оказывающего услуги по расчетно-информационному обслуживанию собственников недвижимого имущества, в оперативную хозяйственную деятельность с целью приращения их стоимости (далее Управляющий РИЦ) составляет план по работе с Дебиторской задолженностью на текущий месяц (он может входить в состав общего ежемесячного плана работы РИЦ). Рекомендуется составлять детальный план по работе с Дебиторской задолженностью с указанием сотрудников, ответственных за выполнения каждого мероприятия, сроков выполнения работ и т.д.

2.Управляющий РИЦ согласовывает план по работе с Дебиторской задолженностью с управляющим УК и управляющим УТЭ до 7 (седьмого) числа текущего месяца и передает на исполнение управляющему инвестированием в услуги по договорному обслуживанию собственников недвижимого имущества (далее - менеджеру ДО).

Осуществление работы по взысканию Дебиторской задолженности:

1.Управляющий инвестированием в услуги по расчетному обслуживанию собственников недвижимого имущества (далее менеджер расчетного отдела РИЦ) не позднее 7 (седьмого) числа каждого месяца предоставляет менеджеру ДО две выписки Должников (по жилому и нежилому фонду) с указанием общей суммы 
долга, суммы долга по каждому дому и суммы долга по каждому помещению по состоянию на 1 (первое) число текущего месяца на бумажном носителе в свободной форме и (или) посредством ИС.

2.Менеджер ДО в течение 2 (двух) дней после получения выписок Должников проводит анализ дебиторской задолженности и группирует Должников в Списки (три Списка на Должников по жилому фонду и три - по нежилому фонду), по следующим критериям:

1 группа: Собственники с Дебиторской задолженностью от 3 (трех) до 4 (четырех) месяцев;

2 группа: Собственники с Дебиторской задолженностью от 4 (четырех) до 6 (шести) месяцев;

3 группа: Собственники с Дебиторской задолженностью свыше 6 (шести) месяцев или суммой долга свыше 4,5 минимальных размеров оплаты труда.

3.Менеджер ДО, в соответствии с планом по работе с Дебиторской задолженностью, выдает сотрудникам ДО Списки в работу и контролирует ее выполнение.

4.Менеджер ДО на основании отметок сотрудников ДО в Списках Должников еженедельно вносит информацию о работе с Дебиторской задолженностью в Аналитическую таблицу, которая ведется в электронном виде и располагается на системном диске. По окончании работ со Списками Должников, последние могут быть утилизированы.

5.На основании записей Аналитической таблицы в срок до 7 (седьмого) числа каждого месяца менеджер ДО предоставляет управляющему РИЦ Отчет по работе с Дебиторской задолженностью.

Управляющий РИЦ использует Отчет для оценки эффективности работы ДО и для отчета перед УК по работе с Дебиторской задолженностью.

Хранение Отчетов по работе с Дебиторской задолженностью осуществляется в электронном виде в ИС в рамках создания письма «Ежемесячный отчет оплачено/начислено за 20 г. ».

Методы по работе с должниками за жилищно-коммунальные услуги:

Помимо стандартных методов возврата задолженности, исходя из многолетнего опыта ведения дел по взысканию дебиторской задолженности, можно предложить следующий эффективный метод по взысканию задолженности.

Он включает в себя целый комплекс мероприятий, направленный на получение положительного результата по реальному получению денежных средств.

Комплекс можно разделить на 2 группы:

1. Досудебное взыскание задолженности:

Ни для кого не секрет, что грамотные переговоры с должником и убедительные доводы, направленные на мотивацию оплаты в досудебном порядке, являются самым быстрым и эффективным способом взыскания долга.

В случае, если местонахождение Должника и его контакты известны, то необходимо проинформировать его о просроченной оплате, а также о 
последствиях, которые наступят в случае неоплаты коммунальных платежей. Необходимо корректно, чётко и доступно изложить информацию перед должником, привести примерные подсчёты убытков, которые может он понести, если не откажется от своей неправильно выбранной позиции.

Можно использовать все современные технические методы передачи информации. Проводить телефонные переговоры с собственниками по своевременной оплате ЖКУ, отправлять SMS-сообщения, факсы, электронные и почтовые письма. То есть, необходимо выработать у Должника осознания своей неправоты и желания погасить долг до суда.

В случае, когда Должник скрывается и его местонахождение неизвестно, то необходимо применить меры по его поиску. Осуществить сбор информации, касающейся местонахождения Должника от третьих лиц. Можно осуществить выезд в предполагаемое место проживания, ненавязчиво опросить соседей. Также необходимо проинформировать по месту работы Должника о его непогашенной задолженности, вести очные переговоры непосредственно с работодателем.

2. Судебный порядок взыскания задолженности:

Этот метод взыскания задолженности применяется в случае отказа Должника погашать задолженность в досудебном порядке. Судебное взыскание начинают с оценки перспектив взыскания долга по коммунальным платежам, что включает в себя всестороннее изучение документов, на основании которых возникла задолженность, производится анализ договоров и иных заслуживающих внимания документов. Уже до обращения в суд Должнику необходимо сообщить о возможных рисках и проинформировать о предположительных результатах судебного процесса по взыскании долга, изучить самостоятельно и разъяснить простым и понятным языком о судебной практике по аналогичным делам.

В комплекс мероприятий по взысканию задолженности в судебном порядке входит составление и направление судебных документов (исковые заявления, ходатайства и прочие необходимые документы), осуществление представительства на судебных заседаниях, после вступления решения суда в силу - передача исполнительного листа и заявления на возбуждение исполнительного производства.

Необходимо осуществлять контроль над ходом взыскания денежных средств на любой стадии производства, вплоть до получения долга. 


\section{Литература}

1. Конституция Российской Федерации

2. Гражданский кодекс Российской Федерации

3. Жилищный кодекс Российской Федерации

4. Налоговый кодекс Российской Федерации

5. Федеральный закон №152-Ф3 от 27.07.2006г. (в ред. от 3 июля 2016 г. № 231-Ф3) «О персональных данных»

6. Приказ Госстроя РФ №142 от 21.04.2003г. «Об утверждении порядка инвентаризации дебиторской задолженности и кредиторской задолженности предприятий и организаций жилищно-коммунального комплекса»

7. Постановление Правительства РФ №307 от 23.05.2006г. (в ред. от 6 мая 2011г. №354) «О порядке предоставления коммунальных услуг гражданам»

8. Постановление Правительства РФ №491 от 13.08.2006г. (в ред. от 9 июля 2016г. №649) «Об утверждении правил содержания общего имущества в многоквартирном доме и правил изменения размера платы за содержания и ремонт жилого помещения в случае оказания услуг и выполнения работ по управлению, содержанию и ремонту общего имущества в многоквартирном доме ненадлежащего качества и (или) с перерывами, превышающими установленную продолжительность» 